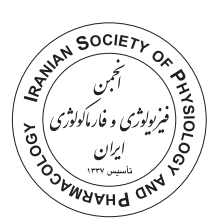

\title{
Nicotine effects on enzymatic antioxidant defenses in human breast and ovarian cell lines
}

Amir Yarahmadi ${ }^{1,2}$, Neda Mohammadi ${ }^{1}$, Fatemeh Zal ${ }^{1,3^{*}}$ (iD)

1. Department of Biochemistry, School of Medicine, Shiraz University of Medical Sciences, Shiraz, Iran

2. Transplant Research Center, Shiraz University of Medical Sciences, Shiraz, Iran

3. Research Center for Traditional Medicine and History of Medicine, Shiraz University of Medical Sciences, Shiraz, Iran

\section{ABSTRACT}

Introduction: Nowadays, the prevalence of nicotine abuse among women has increased

Keywords: dramatically. In the current study, we aimed to investigate the effect of nicotine exposure on Nicotine breast MCF-7 and ovarian OVCAR-3 cell lines for assessing the toxicity of nicotine in the Antioxidant enzymes cells of these organs.

Methods: The MCF-7 and OVCAR-3 cells were treated with increasing nicotine Oxidative stress concentrations ranging from 0 (control), $10^{-11}, 10^{-8}$ and $10^{-6} \mathrm{M}$ for $24 \mathrm{~h}$. Effect of nicotine MCF-7 cells treatments on major antioxidant enzymes catalase (CAT), glutathione peroxidase (GPx), OVCAR-3 cells glutathione reductase (GR), cellular levels of glutathione (GSH) and malondialdehyde (MDA) were monitored.

Results: We showed that the CAT activity in MCF-7 cells increased only at $10^{-6} \mathrm{M}$ dose of nicotine. The GPx and GR activity was decreased at $10^{-8}$ and $10^{-6} \mathrm{M}$ of nicotine in MCF-7 cells, but in OVCAR-3 cells, this decrease was significant only at $10^{-6} \mathrm{M}$ dose of nicotine. Reduced GSH decrease was statistically significant only at $10^{-8}$ and $10^{-6} \mathrm{M}$ of nicotine in MCF-7 cells; otherwise, in OVCAR-3 cells, this decline was significant only at $10^{-6} \mathrm{M}$ of nicotine. Nicotine at $10^{-8}$ and $10^{-6} \mathrm{M}$ concentration caused a significant increase in MDA levels in MCF-7 cells.

Conclusion: This study showed that breast MCF-7 cells are more vulnerable than ovarian OVCAR-3 cells against nicotine-induced oxidative toxicity.

\section{Introduction}

Nicotine, the substantial toxic constituent of cigarette smoke, has various side effects on our body's cellular functions (Delijewski et al., 2014; Zal et al., 2020). It has been shown that nicotine through induction of reactive oxygen species (ROS) shows its toxicity in human cells (Yarahmadi et al., 2017). These ROS initiate and promote oxidative damage to cells in the form of lipid peroxidation, changes in antioxidant enzyme status and finally, cell death (Muthukumaran et al., 2008; Yarahmadi et al., 2018). The human body's defense against ROS harmful effects are mediated through enzymatic and non-enzymatic antioxidants. The enzymatic antioxidant defenses in human cells consist of superoxide dismutase (SOD), catalase (CAT), glutathione peroxidase (GPx) and glutathione reductase (GR) (Aghagolzadeh et

\footnotetext{
* Corresponding author: Fatemeh Zal, zalf@sums.ac.ir

Received 1 April 2020; Revised from 17 December 2020; Accepted 26 December 2020
}

Citation: Yarahmadi A, Mohammadi N, Zal F. Nicotine effects on enzymatic antioxidant defenses in human breast and ovarian cell lines. Physiology and Pharmacology 2021; 25: 279-287. http://dx.doi.org/10.52547/ppj.25.3.279 
al., 2017; Hasanpour et al., 2018). Non-enzymatic antioxidants, including glutathione (GSH), antioxidant vitamins such as $\mathrm{A}, \mathrm{E}$ and $\mathrm{C}$, are other defense mechanisms for protecting cells against the harmful effect of ROS (Alamdari et al., 2020a; Birben et al., 2012).

Previous in vitro and in vivo experiments proved that nicotine administration resulted in a prooxidant-antioxidant imbalance in cellular and animal models (Sudheer et al., 2005; Sudheer et al., 2007). Increased oxidative stress and consequent lipid peroxidation has been linked to have a significant role in nicotine related diseases like cancer (Bartsch and Nair, 2006; Hecht, 2002). It has been demonstrated that smoking is associated with an increased risk of cancers such as lung, breast, ovary, bladder and so on (Dasgupta et al., 2009; Djordjevic et al., 2000). It is estimated that nearly 250 million women worldwide smoke cigarettes and more than a million uses smokeless tobacco products containing nicotine (Sieminska and Jassem, 2014). Because of the increasing use of cigarettes among women globally, we decide to examine the adverse effects of nicotine on breast MCF-7 and ovarian OVCAR-3 cells for assessing the toxicity of nicotine in the cells of this organ. The purpose of the current study was to evaluate the effect of nicotine on enzymatic antioxidant defenses and also malondialdehyde (MDA) as lipid peroxidation maker in human MCF-7 and OVCAR-3 cells in an in vitro model.

\section{Material and methods}

\section{Materials}

Nicotine was obtained from Sigma Chemical Co (Poole, Dorset, UK); cell culture material including RPMI-1640, fetal bovine serum (FBS), penicillin, streptomycin were from Gibco-BRL (Paisley, UK). BSA total protein assay kit was purchased from Bio-Rad (Hercules, California, USA). Nicotinamide adenine dinucleotide phosphate (NADPH), ethylenediaminetetraacetic acid (EDTA) and other material were from sigma unless mentioned.

\section{Cell culture procedure and treatment}

The MCF-7 and OVCAR-3 cell lines were obtained from the cell bank of Pasteur Institute of Iran. The cells were cultured in the following condition: RPMI-1640 medium, $10 \%(\mathrm{v} / \mathrm{v})$ heat-inactivated FBS, $1 \%(\mathrm{v} / \mathrm{v})$ penicillin-streptomycin and then put in $5 \% \mathrm{CO}_{2}$ humidified incubator at $37^{\circ} \mathrm{C}$. All experiments were done only at cells with a minimum of $70 \%$ confluences. Then $5 \times 10^{5}$ cells were seeded in a culture flask $\left(25 \mathrm{~cm}^{2}\right)$ and incubated with increasing nicotine concentrations ranging from $10^{-11}$ to $10^{-6} \mathrm{M}$ for $24 \mathrm{~h}$.

\section{Cell viability assay}

To assess the viability of MCF-7 and OVCAR-3 cells treated with different nicotine concentrations, an assay was carried out using 3-(4, 5-dimethylthiazol-2-yl)-2, 5 diphenyltetrazolium bromide (MTT) as previously described by Mosmann (1983). The MTT assay is a colorimetric assay that relies on the conversion of yellow tetrazolium bromide (MTT) to purple formazan derivative by mitochondrial succinate dehydrogenase in viable cells. First, cells in a 96-well plate were incubated with $0,10^{-12}, 10^{-10}, 10^{-8}, 10^{-6}, 10^{-4}$ and $10^{-2} \mathrm{M}$ nicotine for $24 \mathrm{~h}$ at $37^{\circ} \mathrm{C}$. Then, cells were incubated with MTT $(0.5 \mathrm{mg} / \mathrm{ml})$ dissolved in serum-free medium. After $3.5 \mathrm{~h}$ incubation, $100 \mu 1 \mathrm{DMSO}$ was added to dissolve the formazan crystals and then, absorbance was determined at 570/650nm wavelength using an ELISA reader (BioRad, USA). Cell viability was determined as the ratio of absorbance of treated cells to that of untreated cells that served as a control.

\section{Measurement of CAT activity}

For the determination of CAT activity, we used a method previously described by Aebi (1984). In this method, we spectrophotometrically assessed the decomposition of $\mathrm{H}_{2} \mathrm{O}_{2}$ to $\mathrm{H}_{2} \mathrm{O}$ and $\mathrm{O}_{2}$. Then, enzyme activity was shown as mmol $\mathrm{H}_{2} \mathrm{O}_{2}$ consumed/min per mg MCF7 and OVCAR-3 cell lysate protein by a molar absorptivity of $43.6 \mathrm{~mol} \mathrm{~L}^{-1}$ per $\mathrm{cm}$.

\section{Measurement of GPx activity}

The GPx activity has been evaluated by the method described by Fecondo and Augusteyn based on monitoring continuous substitution of GSH from its oxidized form G-S-S-G in the presence of enzyme GR (Fecondo and Augusteyn, 1983). We also used $\mathrm{Na}_{2}$ salt of NADPH to assess GPx activity according to a previous publication (Mostafavi-Pour et al., 2008). Furthermore, the GPx enzyme activity in the MCF-7 and OVCAR-3 cell lysate was showed as $\mu \mathrm{mol}$ of NADPH oxidized $/ \mathrm{min} / \mathrm{mg}$ of cell protein using a molar absorptivity of $6.22 \times 10^{6}$ $\mathrm{M}^{-1} \mathrm{~cm}^{-1}$ for NADPH. One unit of GPx is determined as $\mathrm{U} / \mathrm{mg}$ of cell protein. 


\section{Measurement of GR activity}

The enzyme GR activities were estimated through a method formerly reported by Racker and Carlberg with little changes (Carlberg and Mannervik, 1985; Racker, 1955). For determination of GR activity, $60 \mu \mathrm{M}$ buffer, 5mM EDTA with $\mathrm{pH}$ 8.0, 0.033M GS-SG, 2mM NADPH and a sample of MCF-7 and OVCAR-3 cell lysate in a final volume of $1000 \mu \mathrm{l}$ were used. The reduction in absorbance shows the oxidation of NADPH throughout the reduction of GS-SG by enzyme GR activity in the MCF-7 and OVCAR-3 cell lysate, which has been monitored for $3 \mathrm{~min}$ at $340 \mathrm{~nm}$ by a Shimadzu Spectrophotometer. Finally, the results were reported through a molar absorptivity of $6.22 \times 10^{6} \mathrm{M}^{-1} \mathrm{~cm}^{-1}$ for NADPH. One unit of GR is defined as U/mg cell protein.

\section{Determination of GSH}

Assessment of GSH with 5, 5-dithio-bis (2- nitrobenzoic) acid (DTNB) was performed according to standard Ellman's method (Mashhoody et al., 2014; Zal et al., 2014). We used $1 \mathrm{mM}$ solutions of reduced GSH to draw a Standard curve. The GSH amount was assayed in MCF-7 and OVCAR-3 cell lysate. For measurement of GSH level, $2.3 \mathrm{ml}$ potassium phosphate buffer $0.2 \mathrm{M}$ with PH 7.6 was added to $500 \mu \mathrm{l}$ of DTNB $(0.001 \mathrm{M})$ solution and then mixed with $200 \mu$ of MCF-7 and OVCAR-3 cell lysate. Finally, the above solution's absorbance was read after $5 \mathrm{~min}$ by a Shimadzu Spectrophotometer at $412 \mathrm{~nm}$.

\section{Determination of $M D A$}

The MDA was measured according to a colorimetric procedure. First, a mixture of the following solution was prepared: $2 \mathrm{ml}$ TBA0.37\%, $15 \%$ trichloroacetic acid, $0.25 \mathrm{~mol} / \mathrm{l} \mathrm{HCL}$ and $500 \mu \mathrm{l} \mathrm{MCF}-7$ or OVCAR-3 cell lysate. Then, the above mixture was put in a water bath at $95^{\circ} \mathrm{C}$ for $30 \mathrm{~min}$ and after rapid cooling, it was centrifuged at $8000 \mathrm{~g}$ for $15 \mathrm{~min}$. After centrifugation, the supernatant's absorbance was measured by a spectrophotometer at $532 \mathrm{~nm}$. The MDA level was calculated based on tetraethoxypropane as standard and expressed as $\mathrm{nmol} / \mathrm{mg}$ cell protein.

\section{Measurement of total protein}

After $24 \mathrm{~h}$ treatment with nicotine, MCF-7 and OVCAR-3 cells were washed with PBS four times and lysed with the lysis buffer containing $50 \mathrm{mM}$ Tris-
$\mathrm{HCl}(\mathrm{pH} 7.4), 0.1 \%$ sodium deoxycholate, $0.1 \%$ SDS, $0.1 \mathrm{mM}$ EDTA, $1.0 \%$ Triton $\mathrm{X}-100$ and $50 \mathrm{mM}$ sodium fluoride. Lysates were incubated at $4^{\circ} \mathrm{C}$ for $20 \mathrm{~min}$ and centrifuged at $20000 \mathrm{~g}$ for $10 \mathrm{~min}$. Then, supernatants were collected in Eppendorf tubes for protein and enzymatic measurements. Protein content was determined using BSA as a standard with Bio-Rad total protein assay kit according to manufacture protocols (Bio-Rad, Hercules, CA, USA).

\section{Statistical analysis}

GraphPad Prism version 6.01 (GraphPad Software, San Diego, CA, USA) and SPSS18 software (SPSS, Chicago, IL, USA) were used for group comparison. The data presented here were analyzed by the Kruskal-Wallis test, followed by Dunn's multiple comparisons test and a difference with $P$-value $\leq 0.05$ was used as the level of significance.

\section{Results}

In the current study, to determine the toxic effect of nicotine exposure on antioxidant defense systems in both MCF-7 and OVCAR-3 cell lines, the cellular activities of CAT, GPx, GR and also the level of reduced GSH and MDA were assayed after 24h of treatment. MCF-7 and OVCAR-3 cell lines were exposed to nicotine doses ranging from $10^{-11}, 10^{-8}$, and $10^{-6} \mathrm{M}$ for $24 \mathrm{~h}$, respectively.

Effect of nicotine treatment on the viability of $M C F-7$ and OVCAR-3 cells

The viability of cultured MCF-7 and OVCAR-3 cells exposed to different nicotine concentrations are presented in Figure 1. As shown in Figure 1, all the nicotine concentrations below $10^{-4} \mathrm{M}$ are safe for in vitro uses compared with the control group.

Effect of nicotine on CAT activity in $M C F-7$ and $\mathrm{OV}$ CAR-3 cells

It has been demonstrated that the activity of CAT in the MCF-7 cell line increased with rising concentrations of nicotine. The treatment of MCF-7cells with $10^{-11}, 10^{-8}$ and $10^{-6} \mathrm{M}$ concentrations of nicotine made an increase in CAT activity by $34 \%, 30.77 \%$ and $44.46 \%$ respectably as compared to controls, which was significant only at $10^{-6} \mathrm{M}$ dose of nicotine (Figure 2A). The CAT activity in OVCAR-3 cells after exposure to doses $10^{-11}, 10^{-8}$ and $10^{-6} \mathrm{M}$ of nicotine was increased by $9.71 \%, 21.99 \%$ and 
$\mathbf{A}$

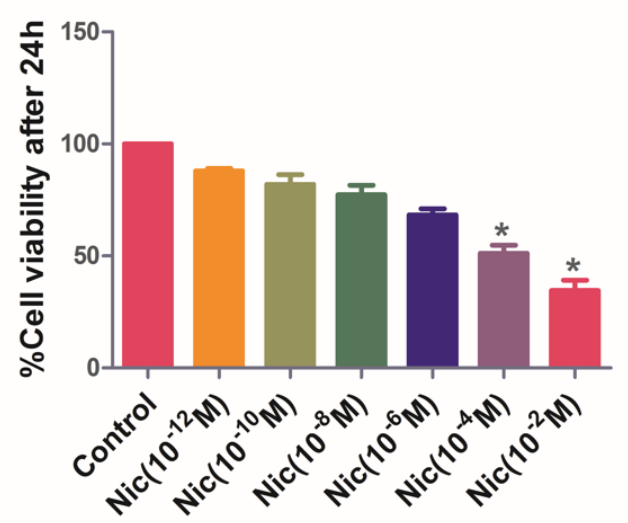

B

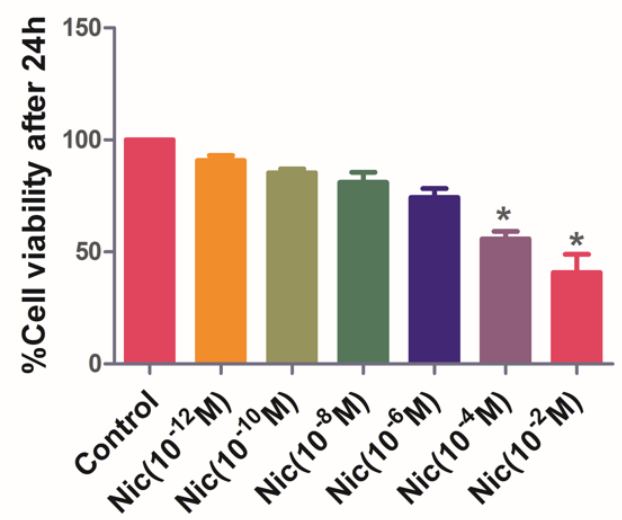

FIGURE 1. Effect of nicotine on the viability of A- MCF-7 and B- OVCAR-3 cells after $24 \mathrm{~h}$ treatment using the MTT assay. Data are presented as mean $\pm \mathrm{SD}(\mathrm{n}=4)$. All data are presented as a percentage with respect to control ( $100 \%$ cell viability). ${ }^{*}$ Shows a significant difference compared to the respective control group $(P<0.05)$.

$\mathbf{A}$

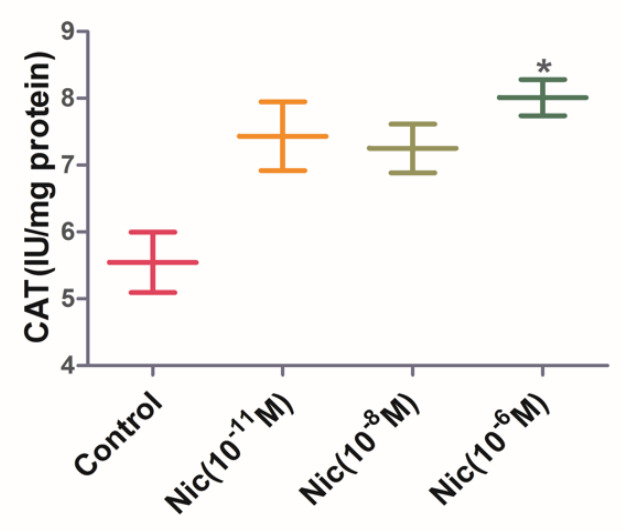

B

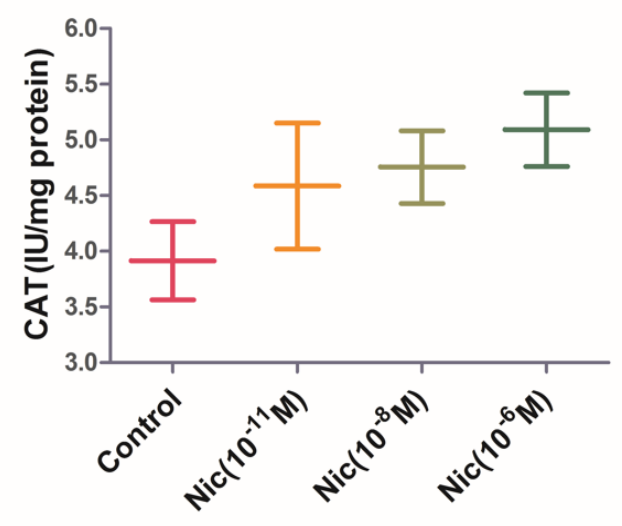

FIGURE 2. Effect of nicotine on CAT activity in A- MCF-7 and B- OVCAR-3 cells. Sample size ( $\mathrm{n}=3)$. $* P<0.05$ for significant changes compared to the control (no treatment). CAT: Catalase.

$\mathbf{A}$

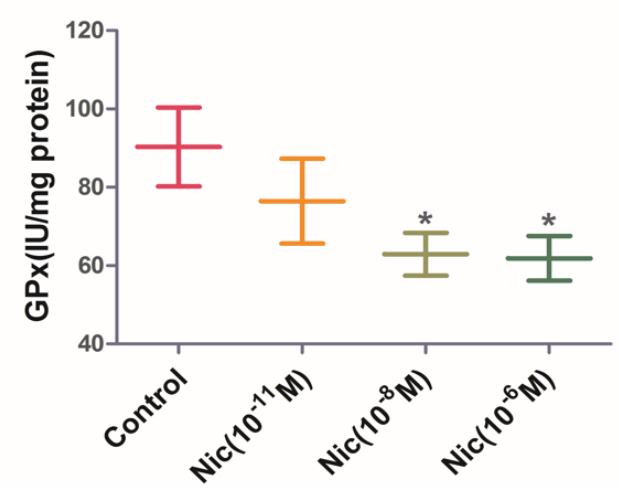

B

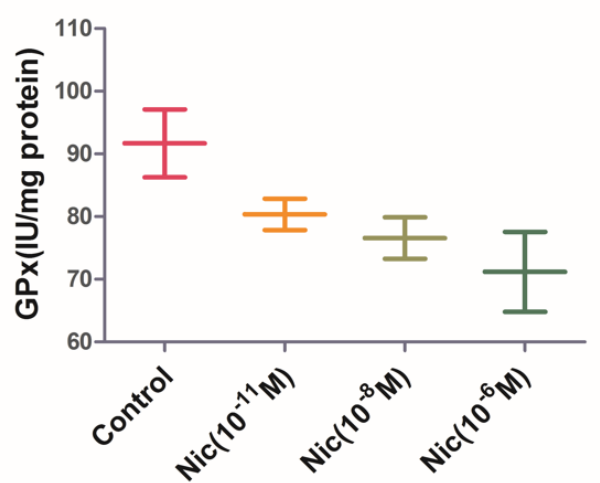

FIGURE 3. Effect of nicotine on GPx activity in A- MCF-7 and B- OVCAR-3 cells. Sample size ( $\mathrm{n}=3)$. ${ }^{*} P<0.05$ for significant changes compared to the control (no treatment). GPx: Glutathione peroxidase. 
$30.17 \%$, respectably, but this increase was not statistically significant (Figure 2B).

Effect of nicotine on GPx activity in $M C F-7$ and $\mathrm{OV}$ CAR-3 cells

In MCF-7 cells, the intracellular GPx activity decreased by $15.31 \%, 30.32 \%$ and $31.48 \%$ for cells treated with $10^{-11}, 10^{-8}$ and $10^{-6} \mathrm{M}$ nicotine concentrations, respectively (Figure 3A). This decrease was significant only at $10^{-8}$ and $10^{-6} \mathrm{M}$ nicotine concentrations compared to the control group $(P<0.05)$. In the case of OVCAR-3 cells, treatment of this cell with the doses $10^{-11}, 10^{-8}$ and $10^{-6} \mathrm{M}$ of nicotine resulted in a decline in GPx activity by $12.37 \%, 16.47 \%$ and $22.25 \%$, respectively. However, these decreases were not significant in all groups compared to the control group (Figure 3B).

Effect of nicotine on GR activity in MCF-7 and $\mathrm{OV}$ CAR-3 cells

As demonstrated in Figure 4A, GR enzymes' activities in the MCF-7 cell line were significantly decreased in cells treated with $10^{-8}$ and $10^{-6} \mathrm{M}$ of nicotine by $37.34 \%$ and $42.36 \%$, respectively, in comparison with the control group. In OVCAR-3 cells, treatment with $10^{-11}, 10^{-8}$ and $10^{-6} \mathrm{M}$ concentration of nicotine decreased the activity of GR by $7.36 \%, 6.27 \%$ and $17.37 \%$, respectively, as compared with the control (no treatment), but this decrease was significant only at $10^{-6} \mathrm{M}$ dose of nicotine $(P<0.05$, Figure 4B).
A

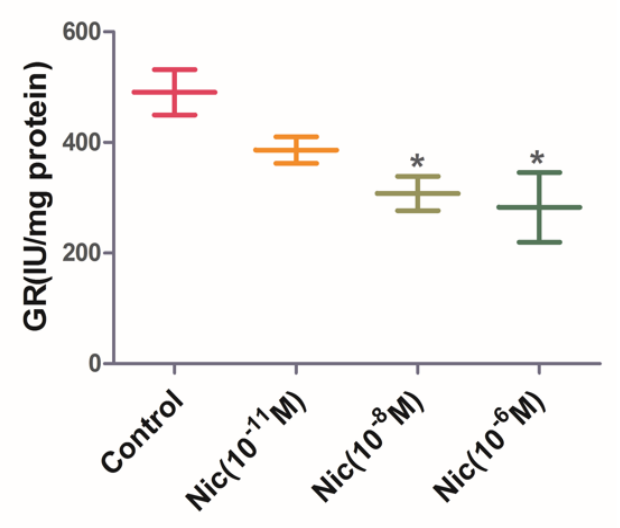

B

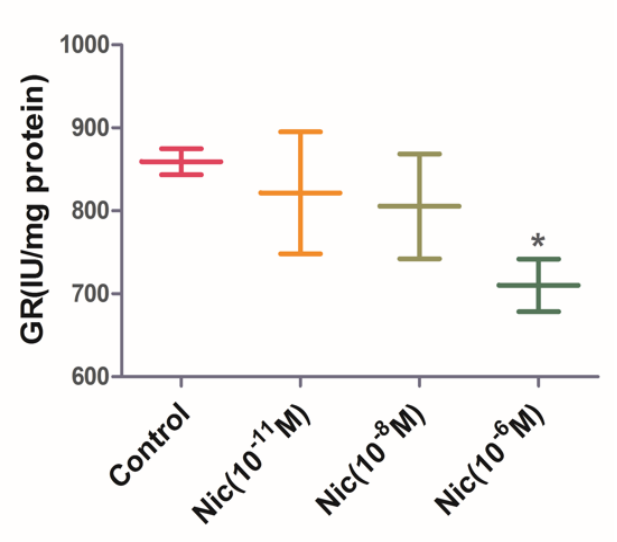

FIGURE 4. Effect of nicotine on GR activity in A- MCF-7 and B- OVCAR-3 cells. Sample size $(\mathrm{n}=3) .{ }^{*} P<0.05$ for significant changes compared to the control (no treatment). GR: Glutathione reductase.

A

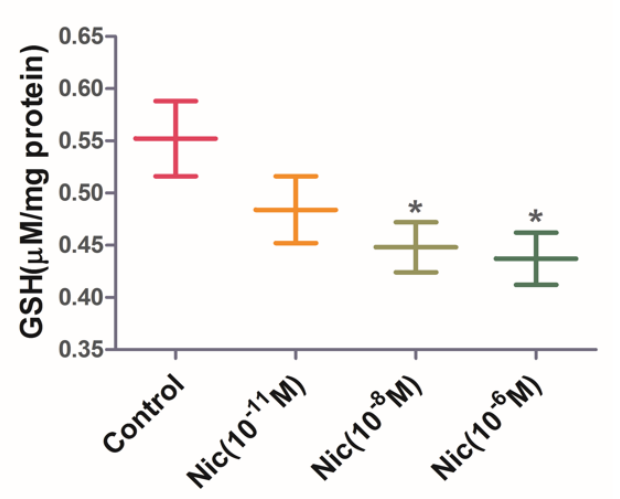

B

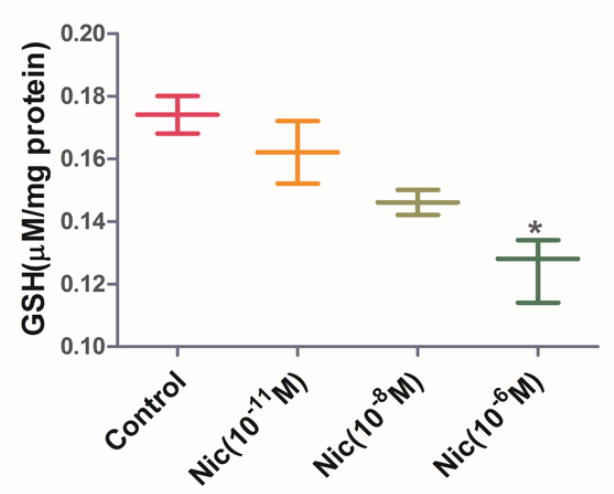

FIGURE 5. Effect of nicotine on GSH level in A- MCF-7 and B- OVCAR-3 cells. Sample size ( $\mathrm{n}=3) .{ }^{*} P<0.05$ for significant changes compared to the control (no treatment). GSH: Glutathione. 
A

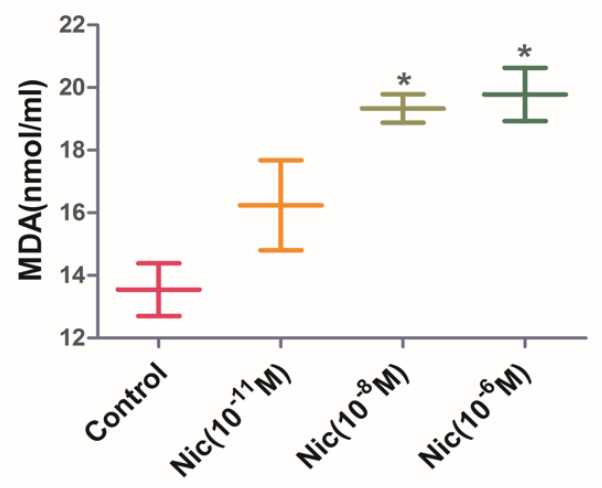

B

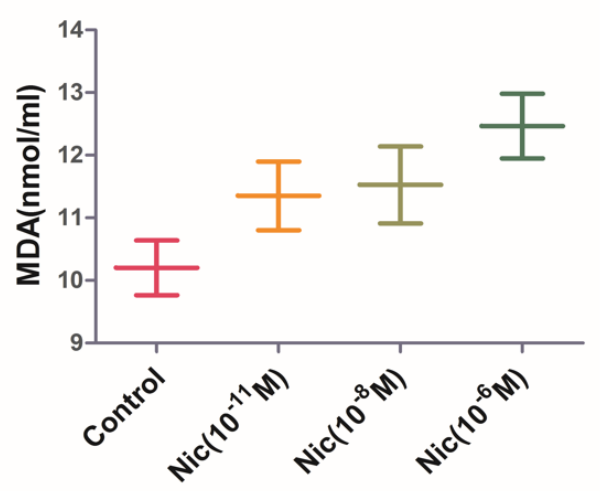

FIGURE 6. Effect of nicotine on MDA level in A- MCF-7 and B- OVCAR-3 cells. Sample size $(\mathrm{n}=3) .{ }^{*} P<0.05$ for significant changes compared to the control (no treatment). MDA: Malondialdehyde.

Effect of nicotine on GSH level in MCF-7 and $\mathrm{OV}$ CAR-3 cells

The GSH level in the MCF-7 cells after 24h of treatment with $10^{-11}, 10^{-8}$ and $10^{-6} \mathrm{M}$ nicotine showed a reduction by $12.32 \%, 18.85 \%$ and $20.84 \%$, respectively in comparison to the control group, but this decrease was significant only at $10^{-8}$ and $10^{-6} \mathrm{M}$ nicotine concentration (Figure 5A). Similarly, in OVCAR-3 cells, the GSH level in cells after $24 \mathrm{~h}$ of treatment with $10^{-11}, 10^{-8}$ and $10^{-6} \mathrm{M}$ of nicotine showed a decline by $6.9 \%, 16.1 \%$ and $26.44 \%$ as compared with the control group, but these declines were significant only at $10^{-6} \mathrm{M}$ nicotine concentration (Figure 5B).

Effect of nicotine on MDA level in MCF-7 and $\mathrm{OV}$ CAR-3 cells

As shown in Figure 6A in MCF-7 cells, nicotine at $10^{-8}$ and $10^{-6} \mathrm{M}$ concentration provoked a significant increase in MDA level by $42.02 \%$ and $45.56 \%$, respectively, compared to the control group $(P<0.05)$. Comparably, in OVCAR-3 cells, nicotine increased MDA level by $11.07 \%, 11.86 \%, 18.72 \%$ in compression with the control group, but these increases were not significant in all three groups (Figure 6B).

\section{Discussion}

The purpose of the current study was to evaluate the toxic effects of nicotine on breast MCF-7 and ovary OVCAR-3 cells in an in vitro experimental model system as a means to understand the toxicity of nicotine in these cells. We showed that nicotine at doses below $10^{-4}$ $\mathrm{M}$ is safe for MCF-7 and OVCAR-3 cells, which is con- sistent with our previous studies on nicotine effects on human HepG2 and endometrial stromal cells (Totonchi et al., 2016; Yarahmadi et al., 2017). Hence, we used $10^{-11}, 10^{-8}$ and $10^{-6} \mathrm{M}$ nicotine to treat MCF-7 and OVCAR-3 cells to assess nicotine effects on the antioxidant enzyme status. The ROS are byproducts of normal cell metabolism and rise in many drug exposure. Depending on their cellular concentration, these free radicals could have beneficial or harmful effects on human cells and tissues (Circu and Aw, 2010). At limited quantities, ROS function like redox messengers in many signaling and regulatory pathways in cells. Nevertheless, the over-production of ROS induces oxidative toxicity and severe damages to basic macromolecules in the cells, such as DNA, proteins and lipids, which destroys normal proteins and lipids function and leads to cell death (Delijewski et al., 2014; Hwang et al., 2008). Many studies also showed that the over-production of ROS disturbers cellular signaling and finally, leads to cancer occurrence (Pelicano et al., 2004). Normal cell function depends on a balance between the production and destruction of free radicals, known as oxidant-antioxidant balance (Alamdari et al., 2020b; Halliwell, 2007). Human body cells consist of a complex antioxidant defense system include enzymatic defense CAT, SOD, GPx and GR and non-enzymatic antioxidant GSH, vitamin $\mathrm{C}$ and $\mathrm{E}$. This system is responsible for protecting the destructive effects of ROS (Circu and Aw, 2010). The enzyme SOD functions as the primary cellular defense against the destructive effects of free oxygen radicals by the dismutation of superoxide anion $\left(\mathrm{O}_{2}^{2-}\right)$ to hydrogen peroxide $\left(\mathrm{H}_{2} \mathrm{O}_{2}\right)$ and molecular oxygen $\left(\mathrm{O}_{2}\right)$. Then, sufficient activity of en- 
zymes CAT and GPx are necessary to degrade $\mathrm{H}_{2} \mathrm{O}_{2}$ to $\mathrm{H}_{2} \mathrm{O}$ and $\mathrm{O}_{2}$. The function of enzyme GR is needed to maintain the GSH level sufficient for the activity of GPx (Matés et al., 1999).

In our study, as shown in Figure 2, the activity of the enzyme CAT increased in both MCF-7 and OVCAR-3 cells after treatment with different nicotine concentrations. However, this increase was significant at $10^{-6} \mathrm{M}$ nicotine concentration in MCF-7 cells, which is consistent with our previous study on the effects of nicotine on the antioxidant enzyme status in HepG-2 cells. Similarly, Delijewski et al. (2014) showed that CAT activity in melanocytes significantly increased after $24 \mathrm{~h}$ incubation with different nicotine concentrations. In contrast, Muthukumaran et al. (2008) showed that nicotine induces antioxidant imbalance and reduces CAT activity in the circulation and lung of Wistar rats after 22 weeks of nicotine treatment. This controversy in CAT activity could be explained by the fact that in acute nicotine exposure, cellular CAT activity increases to mitigate nicotine oxidative damages, but in chronic nicotine exposure, depletion in the activity of CAT may be due to decreased synthesis of enzymes or oxidative inactivation of enzyme protein. In Muthukumaran et al.'s study, decreased CAT activity was associated with decreased antioxidant status after chronic nicotine exposure that can be related to insufficient antioxidant potential.

As demonstrated in Figure 3, GPx activity decreased after treatment with all nicotine doses in both MCF-7 and OVCAR-3 cells. However, it was significant only at $10^{-8}$ and $10^{-6} \mathrm{M}$ in MCF-7 cells, which is consistent with Mahapatra et al. (2009) study on nicotine effects in mice peritoneal macrophages in an in vitro model. This decrease in GPx activity along with an increase in CAT activity may show that both pathways of $\mathrm{H}_{2} \mathrm{O}_{2}$ degradation by enzymes CAT and GPx are involved in the destruction of $\mathrm{H}_{2} \mathrm{O}_{2}$ during the high concentration of free radicals induced by nicotine toxication in these cells.

The function of enzyme GR is the preservation of GSH content in its reduced form, which is necessary for the activity of GPx. In our study, the activity of GR was significantly decreased in high dose nicotine treated groups in both MCF-7 and OVCAR-3 cells, which was compatible with the results of Erat et al. (2007) that showed nicotine treatment reduces GR activity in the liver, lungs, heart, stomach, kidney and testicles of rats in an in vivo and in vitro models and also showed that application of vitamin E could restore the activity of GR.

GSH level is crucial for the preservation of cellular oxidant-antioxidant balance. In in our experiment, the level of reduced GSH significantly decreased after treatment with nicotine at doses $10^{-8}$ and $10^{-6} \mathrm{M}$ in MCF-7 cells and at $10^{-6} \mathrm{M}$ nicotine concentration in OVCAR-3 cells, which is compatible with Balakrishnan and Menon (2007) study that showed nicotine decreased reduced GSH in lung, liver and kidney of rats and hesperidin a polyphenolic compounds which are mainly available in citrus fruits restored GSH level.

Similar to our results, Sener et al. (2005) showed that nicotine-induced oxidative damage results in GSH depletion in the bladder and kidney of rats compared to control and amino acids taurine could significantly enhance reduced GSH in these rats. MDA, an indicator of lipid peroxidation, showed a marked increase in both MCF-7 and OVCAR-3 cells. However, it was significant only in MCF-7 cells at $10^{-8}$, and $10^{-6} \mathrm{M}$ nicotine concentration, which is compatible with the results of Al-Malki and Moselhy (2013) that indicated nicotine administration to rats makes a significant elevation in MDA level.

\section{Conclusion}

In conclusion, the results of this study showed that the breast MCF-7 cells are more vulnerable than ovarian OVCAR-3 cells to nicotine-induced oxidative toxicity in an in vitro model. Further studies are needed to assess different nicotine toxicity patterns in cells in the in vitro and in vivo models.

\section{Acknowledgments}

The authors would like to thank Shiraz University of Medical Sciences, Shiraz, Iran, and the Substance Abuse and Mental Health Research Center of Shiraz University of Medical Sciences. This study was supported by grant 95-01-96-13596 from the office of Vice Chancellor for Research at Shiraz University of Medical Sciences.

\section{Conflict of interest}

The authors have no financial interests related to the manuscript. 


\section{References}

Aebi H. Catalase in vitro. Methods Enzymol 1984; 105: 1216. https://doi.org/10.1016/S0076-6879(84)05016-3

Aghagolzadeh M, Moghaddam AH, Seyedalipour B. Olive leaf extract reverses the behavioral disruption and oxidative stress induced by intrastriatal injection of 6-hydroxydopamine in rats. Physiol Pharmacol 2017; 21.

Al-Malki AL, Moselhy SS. Protective effect of vitamin E and epicatechin against nicotine-induced oxidative stress in rats. Toxicol Ind Health 2013; 29: 202-8. https://doi. org/10.1177/0748233711430976

Alamdari DH, Moghaddam AB, Amini S, Alamdari AH, Damsaz M, Yarahmadi A. The application of a reduced dye used in orthopedics as a novel treatment against coronavirus (COVID-19): a suggested therapeutic protocol. Arch Bone Jt Surg 2020a; 8: 291.

Alamdari DH, Moghaddam AB, Amini S, Keramati MR, Zarmehri AM, Alamdari AH, et al. Application of methylene blue-vitamin $\mathrm{C}-\mathrm{N}$-acetyl cysteine for treatment of critically ill COVID-19 patients, report of a phase-I clinical trial. Eur J Pharmacol 2020b; 885: 173494. https://doi. org/10.1016/j.ejphar.2020.173494

Balakrishnan A, Menon VP. Antioxidant properties of hesperidin in nicotine-induced lung toxicity. Fundam Clin Pharmacol 2007; 21: 535-46. https://doi.org/10.1111/j.14728206.2007.00477.x

Bartsch H, Nair J. Chronic inflammation and oxidative stress in the genesis and perpetuation of cancer: role of lipid peroxidation, DNA damage, and repair. Langenbecks Arch Surg 2006; 391: 499-510. https://doi.org/10.1007/s00423006-0073-1

Birben E, Sahiner UM, Sackesen C, Erzurum S, Kalayci O. Oxidative stress and antioxidant defense. World Allergy Organ J 2012; 5: 9-19. https://doi.org/10.1097/WOX $.0 \mathrm{~b} 013 \mathrm{e} 3182439613$

Carlberg I, Mannervik B. Glutathione reductase. Methods Enzymol 1985; 113: 484-90. https://doi.org/10.1016/S00766879(85)13062-4

Circu ML, Aw TY. Reactive oxygen species, cellular redox systems, and apoptosis. Free Radic Biol Med 2010; 48: 74962. https://doi.org/10.1016/j.freeradbiomed.2009.12.022

Dasgupta P, Rizwani W, Pillai S, Kinkade R, Kovacs M, Rastogi $\mathrm{S}$, et al. Nicotine induces cell proliferation, invasion and epithelial-mesenchymal transition in a variety of human cancer cell lines. Int J Cancer 2009; 124: 36-45. https:// doi.org/10.1002/ijc.23894

Delijewski M, Beberok A, Otręba M, Wrześniok D, Rok J,
Buszman E. Effect of nicotine on melanogenesis and antioxidant status in HEMn-LP melanocytes. Environ Res 2014; 134: 309-14. https://doi.org/10.1016/j.envres.2014.08.015

Djordjevic MV, Stellman SD, Zang E. Doses of nicotine and lung carcinogens delivered to cigarette smokers. J Natl Cancer Inst 2000; 92: 106-11. https://doi.org/10.1093/ jnci/92.2.106

Erat M, Ciftci M, Gumustekin K, Gul M. Effects of nicotine and vitamin $\mathrm{E}$ on glutathione reductase activity in some rat tissues in vivo and in vitro. Eur J Pharmacol 2007; 554: 92-7 .https://doi.org/10.1016/j.ejphar.2006.10.008

Fecondo JV, Augusteyn RC. Superoxide dismutase, catalase and glutathione peroxidase in the human cataractous lens. Exp Eye Res 1983; 36: 15-23. https://doi.org/10.1016/00144835(83)90085-4

Halliwell B. Biochemistry of oxidative stress. Biochem Soc Trans 2007; 35: 1147-50. https://doi.org/10.1042/ BST0351147

Hasanpour M, Ashrafi M, Erjaee H, Nazifi S. The effect of saffron aqueous extract on oxidative stress parameters and important biochemical enzymes in the testis of streptozotocin-induced diabetic rats. Physiol Pharmacol 2018; 22: 28-37.

Hecht SS. Tobacco smoke carcinogens and breast cancer. Environ Mol Mutagen 2002; 39: 119-26. https://doi. org/10.1002/em.10071

Hwang JT, Kwon DY, Park OJ, Kim MS. Resveratrol protects ROS-induced cell death by activating AMPK in H9c2 cardiac muscle cells. Genes Nutr 2008; 2: 323-6. https://doi. org/10.1007/s12263-007-0069-7

Mahapatra SK, Das S, Bhattacharjee S, Gautam N, Majumdar S, Roy S. In vitro nicotine-induced oxidative stress in mice peritoneal macrophages: a dose-dependent approach. Toxicol Mech Methods 2009; 19: 100-8. https://doi. org/10.1080/15376510802255184

Mashhoody T, Rastegar K, Zal F. Perindopril may improve the hippocampal reduced glutathione content in rats. Adv Pharm Bull 2014; 4: 155-9.

Matés JM, Pérez-Gómez C, De Castro IN. Antioxidant enzymes and human diseases. Clin Biochem 1999; 32: 595603. https://doi.org/10.1016/S0009-9120(99)00075-2

Mosmann T. Rapid colorimetric assay for cellular growth and survival: application to proliferation and cytotoxicity assays. J Immunol Methods 1983; 65: 55-63. https://doi. org/10.1016/0022-1759(83)90303-4

Mostafavi-Pour Z, Zal F, Monabati A, Vessal M. Protective effects of a combination of quercetin and vitamin $\mathrm{E}$ against 
cyclosporine A-induced oxidative stress and hepatotoxicity in rats. Hepatol Res 2008; 38: 385-92. https://doi. org/10.1111/j.1872-034X.2007.00273.x

Muthukumaran S, Sudheer AR, Menon VP, Nalini N. Protective effect of quercetin on nicotine-induced prooxidant and antioxidant imbalance and DNA damage in Wistar rats. Toxicol 2008; 243: 207-15. https://doi.org/10.1016/j. tox.2007.10.006

Pelicano H, Carney D, Huang P. ROS stress in cancer cells and therapeutic implications. Drug Resist Updat 2004; 7 : 97-110. https://doi.org/10.1016/j.drup.2004.01.004

Racker E. Glutathione reductase from bakers' yeast and beef liver. J Biol Chem 1955; 217: 855-65. https://doi. org/10.1016/S0021-9258(18)65950-2

Şener G, Şehirli Ö, İpçi Y, Çetinel Ş, Çikler E, Gedik N, et al. Protective effects of taurine against nicotine-induced oxidative damage of rat urinary bladder and kidney. Pharmacol 2005; 74: 37-44. https://doi.org/10.1159/000083245

Sieminska A, Jassem E. The many faces of tobacco use among women. Med Sci Monit 2014; 20: 153-62. https:// doi.org/10.12659/MSM.889796

Sudheer AR, Chandran K, Marimuthu S, Menon VP. Ferulic acid modulates altered lipid profiles and prooxidant/antioxidant status in circulation during nicotine-induced toxicity: a dose-dependent study. Toxicol Mech Methods 2005; 15: 375-81. https://doi.org/10.1080/15376520500194783

Sudheer AR, Muthukumaran S, Devipriya N, Menon VP. Ellagic acid, a natural polyphenol protects rat peripheral blood lymphocytes against nicotine-induced cellular and
DNA damage in vitro: with the comparison of N-acetylcysteine. Toxicol 2007; 230: 11-21. https://doi.org/10.1016/j. tox.2006.10.010

Totonchi H, Miladpour B, Mostafavi-Pour Z, Khademi F, Kasraeian M, Zal F. Quantitative analysis of expression level of estrogen and progesterone receptors and VEGF genes in human endometrial stromal cells after treatment with nicotine. Toxicol Mech Methods 2016; 26: 595-600. https://doi.org/10.1080/15376516.2016.1218578

Yarahmadi A, Khademi F, Mostafavi-Pour Z, Zal F. In-Vitro analysis of glucose and quercetin effects on m-TOR and Nrf-2 expression in HepG2 cell line (diabetes and cancer connection). Nutr Cancer 2018: 70: 770-5. https://doi.org/1 $0.1080 / 01635581.2018 .1470654$

Yarahmadi A, Zal F, Bolouki A. Protective effects of quercetin on nicotine induced oxidative stress in 'HepG2 cells'. Toxicol Mech Methods 2017; 27: 609-14. https://doi.org/10.10 80/15376516.2017.1344338

Zal F, Taheri R, Khademi F, Keshavarz E, Rajabi S, Mostafavi-Pour $Z$. The combined effect of furosemide and propranolol on GSH homeostasis in ACHN renal cells. Toxicol Mech Methods 2014; 24: 412-6. https://doi.org/10.3109/15 376516.2014 .926437

Zal F, Yarahmadi A, Totonchi H, Barazesh M, Sarabi MM. Nicotine attenuates global genomic DNA methylation by influencing DNMTs gene expression in human endometrial stromal cells. Genes Environ 2020; 42: 1-8. https://doi. org/10.1186/s41021-020-0144-5 